\title{
ANXIETY, DEPRESSION AND QUALITY OF LIFE IN INDIVIDUALS WITH PHANTOM LIMB PAIN
}

\author{
Mariana Theozzo Padovanl ${ }^{1}$, Marielza Regina Ismael Martins ${ }^{1}$, Alexandre $V_{\text {enâncio }}^{2}$, José Eduardo Nogueira Fornl ${ }^{1}$
}

\begin{abstract}
Objective: This study aims to evaluate emotional factors such as anxiety and depression, and the Quality of Life of individuals with chronic persistent pain after amputation in order to identify the interindividual variation in response to pain. Methods: This was a descriptive, exploratory and cross-sectional study with quantitative approach. Twenty seven patients were interviewed. The instruments have rated the sociodemographic, clinical and economic profile (semistructured interview) and the Quality of Life (generic Quality of Life questionnaire SF-12) and emotional factors (HAD scale) of the interviewed patients. Results: It was identified that the most frequent amputations occur in males aged 18-38 years
\end{abstract}

and are related to occupational accidents. The Quality of Life was compromised in both components of physical and mental health. Furthermore, anxiety levels were more prevalent in the range from aged 18 to 38 years old, while the levels of depression were most prevalent among the elderly (60 to 80 years old). Conclusion: The impairment of Quality of Life and change in the perception of body image has a major impact on adherence to the rehabilitation program and the functional prognosis. Therapeutic orientation is, therefore, critical after this type of surgery. Level of Evidence II, Descriptive and Exploratory Study.

Keywords: Amputation. Chronic pain. Quality of life.

Citation: Padovani MT, Martins MRI, Venâncio A, Forni JEN. Anxiety, depression and quality of life in individuals with phantom limb pain. Acta Ortop Bras. [online]. 2015;23(2):10710. Available from URL: http://www.scielo.br/aob.

\section{INTRODUCTION}

Amputations are characterized by the removal of an organ/limb or part thereof located at the end of the human body. ${ }^{1}$ Etiologies leading to amputation are various and can be divided into vascular causes, such as diabetes mellitus, atherosclerosis and vasculitis, as well as nonvascular causes as trauma, neoplasia, burns, congenital or infectious conditions. ${ }^{2}$ According to the survey of lower limbs amputees treated at Lar Escola São Francisco in São Paulo, SP, Brazil, from 2006 to 2012, the main reasons were vascular causes amputations. ${ }^{3}$

This type of surgical procedure aims to consider what it is available to replace the function of that limb, preferably to its aesthetics. However, amputation and any other surgical procedure can lead to complications, such as bleeding, infection, skin tear, joint contracture and especially phantom limb pain. Furthermore, we must consider the psychological trauma since the patients are faced with a situation that involves a change in their locomotion, work and social living. ${ }^{4}$

Phantom limb pain $(P L P)$ refers to the sensation of pain in the missing part of the amputated limb, presenting in different ways such as a burning sensation, a grip, or a pain which may vary in intensity and frequency. ${ }^{5}$ For a long time, it was believed that the origin of the phantom sensation was psychic.
However, it is known today that this phenomenon is also physiologically related. ${ }^{6}$

There are two theories that explain its pathophysiology. The first considers that this pain is a phenomenon that occurs from top to bottom, i.e. it is triggered by the reorganization of the mapping of structures depicted in the cerebral cortex, in a sensory and motor plasticity process. The second considers that this phenomenon occurs from the bottom up, i.e. it occurs by excessive stimulation and not by its loss, ectopically generated in the primary afferent neurons in the dorsal root ganglion, that before enervated the amputated limb. Among these theories, the first is the most widely accepted. ${ }^{7}$

This kind of pain occurs in $50-80 \%$ of amputation cases and can occur days after surgery for reasons not yet fully understood. ${ }^{8}$ There are factors that may aggravate the pain, among them attention, emotion, touching the stump or pressure, temperature change, autonomous reflexes, pain from other sources, placement of a prosthesis. However, factors that relieve pain include resting, distraction, stump movement, wearing a prosthesis, lifting the stump, percussion or stump massage. ${ }^{9}$

It should be noted that phantom limb pain differs from pain in the stump, or residual limb, which is due to skin complications, vascular compromise, inappropriate healing, painful

All the authors declare that there is no potential conflict of interest referring to this article.

\footnotetext{
1. Faculdade de Medicina de São José do Rio Preto, São José do Rio Preto, SP, Brazil.
}

2. Hospital de Câncer de Barretos, Barretos, SP, Brazil.

Work developed at Pain Clinic and Orthopedics and Traumatology Service - FUNFARME/FAMERP, São José do Rio Preto, SP, Brazil.

Correspondence: Marielza Regina Ismael Martins. Departamento de Ciências Neurológicas, Faculdade de Medicina de São José do Rio Preto, Av. Brigadeiro Faria Lima, 5416 - Vila São Pedro, 15090-000, São José do Rio Preto, SP, Brazil. marielzamartins@famerp.br 
neuromas, excess soft tissue and bone irregularities. ${ }^{10}$ Both types of pain can interfere with the physical and psychosocial rehabilitation of the amputee, compromising the acquisition of skills and quality of life. ${ }^{11}$

The impact of amputation in the experience of any individual translates into changes in his body image, beyond that, it infers on the psychosocial adjustment of individuals who experience the phenomenon, with influence on their self-esteem and the possible emergence of psychopathological symptoms and on social functioning. ${ }^{12}$

Within this context, this study aims to assess emotional factors such as anxiety and depression and quality of life of individuals with post-amputation persistent chronic pain in order to identify the interindividual variation in response to pain and contribute to knowledge and practice of health professionals involved in assisting this population.

\section{MATERIALS AND METHODS}

This is a descriptive, exploratory, cross-sectional study with a quantitative approach. The research project was approved by the Research Ethics Committee of FAMERP (2384/2010) and held at the Pain Clinic Outpatient and Orthopedics and Traumatology Service, Hospital de Base (FUNFARME/FAMERP). Inclusion criteria were patients of both genders aged over 18 years old that have had persistent pain postoperatively to independent amputation whichever body part or level, with cognitive level sufficient to understand the assessments and consent to participate in the study by signing the Post-Informed Consent Term. The evaluation of the subjects was performed using primarily a semi-structured interview with sociodemographic, economic and clinical characteristics (marital status, schooling, age, gender, occupation, housing and family relationships, besides questions about the use of alcohol and tobacco and related diseases), followed by a characterization instrument regarding the amputation surgery (level of amputation, cause leading to surgery and the time of prosthesis use, if it applied). Subsequently an instrument for the analysis of daily activities and practice was applied (sleeping, appetite, deambulation, home activities, work, personal hygiene, bowel movements, interpersonal relationships, concentration, sexual activity, mood and leisure) which were marked with the corresponding values: (1) No alteration (2) Partially compromised. (3) Fully compromised (4) does not apply. Pain was assessed using a visual analog scale (VAS), ${ }^{13}$ which measures the intensity of pain in patients where zero means total absence of pain and 10 maximum pain. Emotional factors such as anxiety and depression were assessed using the HAD scale (Hospital Anxiety and Depression Scale), ${ }^{14}$ which contains 14 multiple-choice questions, seven for anxiety and seven for depression, which has the cut-off point at eight for anxiety and nine for depression. The quality of life was assessed by the generic questionnaire on quality of life SF- $12^{15}$ consisting of 12 questions that address the physical component (functional capacity and limitation due to physical aspects) and the mental component (pain, vitality, social aspects, limitation due to emotional aspects and mental health). All subjects of both groups were subjected to a single assessment.

The descriptive analysis was performed in the Excel software. Qualitative data were analyzed by odds ratio and ordinals by nonparametric tests. All statistical analysis was performed using significance level at 0:05.

\section{RESULTS}

Twenty-seven patients from the Pain Clinic Outpatient and Orthopedics and Traumatology Service, Hospital de Base (FUNFARME/FAMERP) participated in this study, 16 of them being male (59\%) and 11 female (41\%). Among the patients, $38 \%(n=10)$ were young adults (from 18 to 38 years old), 33\% $(n=9)$ were elderly (60-80 years old) and $29 \%(n=8)$ were in the range $39-59$ years old. Mean education was $6.5 \pm 3.0$ years. Of the participants $48 \%(n=13)$ were married, $22 \%(n=6)$ were single, $22 \%$ were widowed and $8 \%(n=2)$ divorced. Most were still working $(n=15 / 55 \%)$.

As for the self perception of the familiar aspects $77 \%(n=21)$ believed they have a good relationship with their family, while $9 \%(n=2)$ considered having a bad relationship. Among the subjects evaluated $22 \%(n=6)$ were smokers and $18 \%(n=4)$ were drinkers. The main diseases that have been reported are associated with diabetes mellitus and hypertension (both with $n=3 / 11 \%)$. Other diseases reported were cirrhosis $(n=1 / 3 \%)$ and chronic renal failure $(n=1 / 3 \%)$. Most respondents own their house $(n=13 / 44 \%)$, while $40 \%(n=12)$ pay rent and $6 \%(n=2)$ live with relatives. Sociodemographic and clinical characteristics are summarized in Table 1.

Chi square test - ${ }^{*} p<0.05$ : significant statistical difference. Regarding daily activities $44.4 \%(n=12)$ of subjects reported sleeping was partially compromised after amputation surgery, while $25.9 \%(n=7)$ reported no change in this regard. Regarding

\begin{tabular}{|c|c|c|c|}
\hline Variables & $\%$ & Mean + SD & $p$ \\
\hline \multicolumn{4}{|l|}{ Gender } \\
\hline $\begin{array}{l}\text { Masculine } \\
\text { Feminine }\end{array}$ & $\begin{array}{l}59(n=16) \\
41(n=11)\end{array}$ & & $0.048^{*}$ \\
\hline \multicolumn{4}{|l|}{ Age (years old) } \\
\hline $\begin{array}{c}18-38 \\
39-59 \\
60-80 \\
\end{array}$ & \begin{tabular}{|l|}
$38(n=10)$ \\
$29(n=8)$ \\
$33(n=9)$ \\
\end{tabular} & $45.6 \pm 17.2$ & 0.056 \\
\hline Schooling (years) & & $6.5 \pm 3.0$ & \\
\hline \multicolumn{4}{|l|}{ Marital status } \\
\hline $\begin{array}{l}\text { Married } \\
\text { Single } \\
\text { Widow } \\
\text { Divorced }\end{array}$ & $\begin{array}{c}8(n=13) \\
22(n=6) \\
22(n=6) \\
8(n=2) \\
\end{array}$ & & $0.028^{*}$ \\
\hline \multicolumn{4}{|l|}{ Occupation } \\
\hline $\begin{array}{c}\text { Works } \\
\text { Does not work }\end{array}$ & $\begin{array}{l}55(n=15) \\
45(n=12) \\
\end{array}$ & & 0.056 \\
\hline \multicolumn{4}{|c|}{$\begin{array}{c}\text { Self perception of familiar } \\
\text { aspects }\end{array}$} \\
\hline $\begin{array}{l}\text { Good } \\
\text { Moderate } \\
\text { Bad }\end{array}$ & $\begin{array}{c}77(n=21) \\
14(n=4) \\
9(n=2)\end{array}$ & & $0.028^{*}$ \\
\hline $\begin{array}{l}\text { Smoker } \\
\text { Drinker }\end{array}$ & $\begin{array}{l}22(n=6) \\
18(n=4)\end{array}$ & & 0.065 \\
\hline \multicolumn{4}{|l|}{ Associated diseases } \\
\hline $\begin{array}{c}\text { Diabetes } \\
\text { Hypertension } \\
\text { Cirrhosis } \\
\text { Cirrhosis } \\
\text { Chronic renal failure }\end{array}$ & $\begin{array}{l}11(n=3) \\
11(n=3) \\
3(n=1) \\
3(n=1) \\
3(n=1)\end{array}$ & & 0.065 \\
\hline \multicolumn{4}{|l|}{ Housing } \\
\hline $\begin{array}{c}\text { Own } \\
\text { Rented } \\
\text { Lives with relatives }\end{array}$ & $\begin{array}{c}44(n=12) \\
40(n=13) \\
6(n=2)\end{array}$ & & 0.058 \\
\hline
\end{tabular}


appetite mostly ( $n=19$ / 70.3\%) reported no change and only $7.4 \%(n=2)$ of patients reported to have partially compromised appetite. As for deambulation $40.7 \%(n=11)$ of patients reported partial impairment, $14.8 \%(n=4)$ of patients reported total impairment and $25.9 \%(n=7)$ had no effect in this regard. One third $(33.3 \%, n=9)$ of the subjects reported no changes in household activities, while $29.6 \%(n=8)$ reported partial impairment of these activities and $11.1 \%(n=3)$ reported total impairment.

Regarding work limitation was greater, $29.6 \%(n=8)$ of patients were totally impaired in this regard, $25.9 \%(n=7)$ had milder impairment and only $22.2 \%(n=6)$ were not impaired at all. As for personal hygiene $29.6 \%(n=8)$ of the subjects reported having partial impairment, while $44.4 \%(n=12)$ reported no change. Fourteen point eight percent $(n=4)$ of the subjects reported total impairment of bowel habits, $22.2 \%(n=6)$ reported partial impairment and $33.3 \%(n=9)$ had no alteration whatsoever. Interpersonal relationships were partially deteriorated to $29.6 \%$ $(n=8)$ of individuals, totally deteriorated to $11.1 \%(n=3)$ and not affected to $40.7 \%(n=11)$ of them.

Concentration was abnormal in $29.6 \%(n=8)$ of patients and in $48.1 \%(n=13)$ it was not altered. Regarding sexual activity $29.6 \%(n=8)$ of respondents reported partial impairment, $14.8 \%$ $(n=4)$ reported total impairment and $25.9 \%(n=7)$ reported no alteration. Humor was the aspect that was most altered, since $40.7 \%(n=11)$ evaluated the reported partial impairment, $22.2 \%$ $(n=6)$ reported total impairment and only $14.8 \%(n=4)$ reported no change at all. (Figure 1)

Regarding the pain sensation, burning was the most common type $(42 \%-n=11)$ followed by "needle type" $(36 \%-n=9)$ and burning feeling $(22 \%-n=7)$. Only seven patients $(25 \%)$ and wore prosthesis. Regarding medication adherence, $51 \%$ $(n=14)$ used medications such as anticonvulsants, antidepressants and anesthetic blocks. Thirteen patients (49\%) reported use of anti-inflammatory or analgesic drugs, without improvement. There were no reports of use of regular or intermittent analgesia prior to amputation. Rehabilitation was done in $70 \%(n=18)$ with orientation such as stump lifting, percussion and massage. (Table 2)

Regarding anxiety and depression the number of patients ranked by the level of severity of symptoms of depression with their mean scores on the Hospital Anxiety and Depression Scale (HAD) are shown in Figure 2.

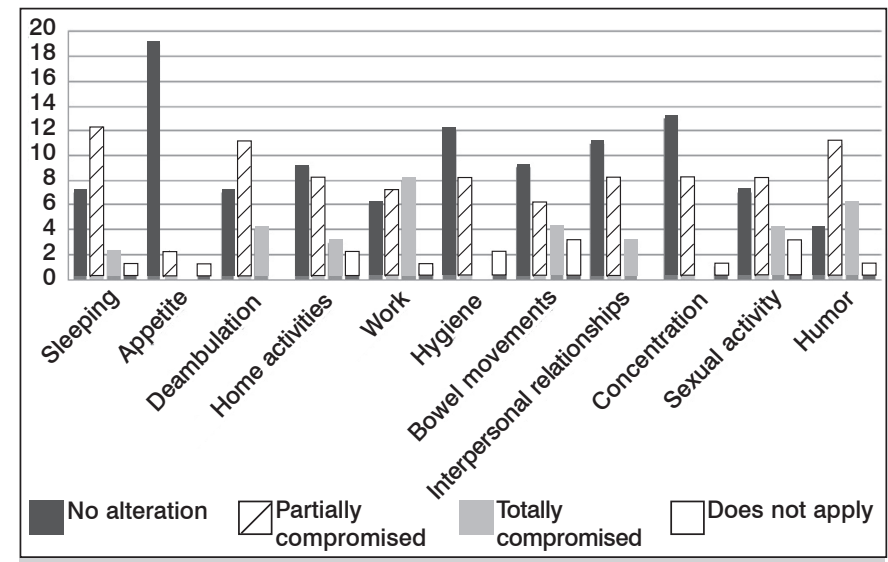

Figure 1. Data on activities of practical daily life on the sample studied $(n=27)$.
It has been noted that anxiety levels were higher (18/27) than depression (11/27), and the quality of life was compromised in both components $(<50)$, where the physical health component was 42 and the mental health component 40 .

The study also included associations between the individual's age and the presence of anxiety and depression. (Figure 3) Importantly, the anxiety levels were more prevalent in the age group of 18-38 years old, while the levels of depression were more prevalent among the elderly (60-80 years old).

Table 2. Data referring to pain levels, cause and amputation and rehabilitation time of the studied sample $(n=27)$.

\begin{tabular}{c|c|cc}
\hline & $\%$ & Mean SD \\
\hline Amputation level & & & \\
\hline Transfemoral & $44(n=12)$ & & \\
Transtibial & $11(n=3)$ & & \\
Transcarpian & $25(n=7)$ & & \\
Transhumeral & $20(n=5)$ & & \\
\hline Pain - VAS & & & \\
\hline Low (0-2) & $25(n=7)$ & & \\
Moderated (3-7) & $44(n=12)$ & & \\
Intense (8-10) & $29(n=8)$ & & \\
\hline Amputation time (months) & & & \\
\hline Causes & & & \\
\hline Work injury & $37(n=10)$ & & \\
Trauma & $18(n=5)$ & & \\
Trombose & $18(n=5)$ & & \\
Cancer & $7(n=2)$ & & \\
Diabetes & $20(n=5)$ & & \\
\hline Rehabilitation time (months) & & & \\
\hline
\end{tabular}

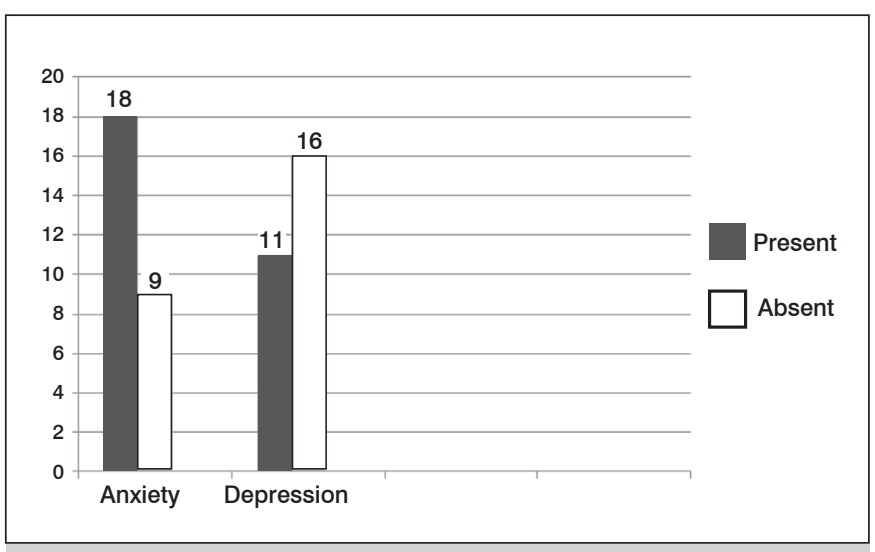

Figure 2. Number of patients by level of severity of depression symptoms and indication of average grades $(n=27)$.

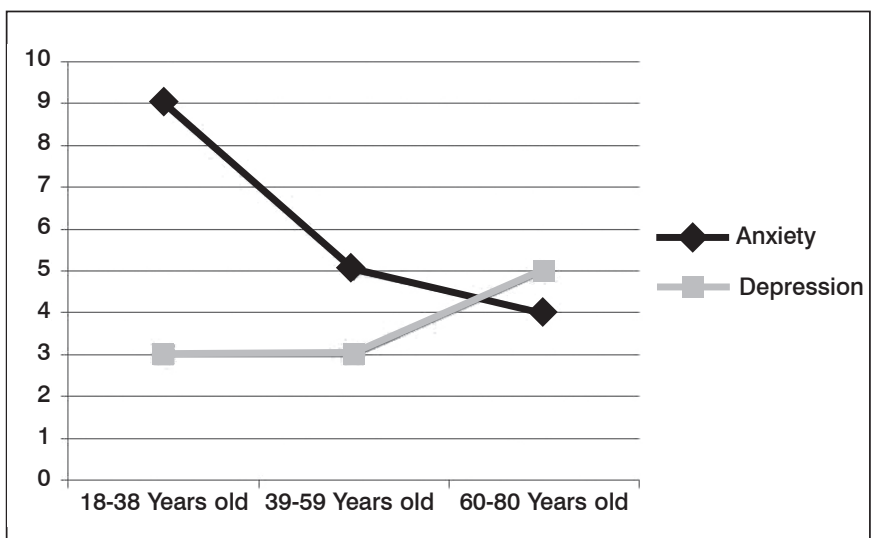

Figure 3. Association between age of individuals in sample and presence of anxiety and depression $(n=27)$ 


\section{DISCUSSION}

This study investigated the sociodemographic and clinical characteristics of patients from Pain Clinic Outpatient and Orthopedics and Traumatology Service, Hospital de Base (FUNFARME/FAMERP) who presented phantom limb pain after amputation surgery, as well as the impairment of daily activities and quality of life of these individuals, besides depressive and anxiety symptoms.

The loss of a limb disrupts the integrity of the body and affects physical and psychological conditions of patients who undergo amputation surgery. This type of surgery means a huge impact, not only for the patient's body and the way he notices it, as well as the perception of the environment around him. ${ }^{16}$ In view of this problem, this cross-sectional study aims to evaluate the quality of life, anxiety and depression in patients with phantom limb pain after amputation surgery, since in Brazil recent studies on this subject are scarce.

Compared to the study of Resende et al. ${ }^{17}$ sociodemographic data were very similar, since in the cited study 21 individuals aged 20-69 years old, mean age of 42.62 years old with limb amputation were evaluated, while the present study evaluated 27 individuals between 18 and 80 years old with a mean age of 45.6 years old. In both most individuals were male $(71.4 \%$ and $59 \%)$. In that study ${ }^{17}$ the majority of respondents were married $(47.6 \%)$, as well as in the present study (48\%). In both studies, most patients remain employed and in the cited study $71.4 \%$ had their own income, as compared with 55\% in this study.

Regarding to clinical aspects, in both studies, the major cause of amputation were accidents (81\% and 37\%). However, most of amputations in this study was of the lower limbs (55\%), while in the study of Resende et al. ${ }^{17}$ it was the upper limbs (67.3\%), likewise, most patients did not use prosthesis (71.4\% and $75 \%$ ). In the present study, only seven individuals (25\%) wore prosthesis. As to daily living activities, this study reveals that most of them are partially or totally compromised, except appetite. Activities such as working and humor proved to be the most affected. According to the study of Batista et al. ${ }^{18}$ this compromise occurs due to the experience of a daily life permeated by difficulties, limitations and restrictions imposed by amputation; suffering by dependence

\section{REFERENCES}

1. Both JE, Badke MR, Daandels N, Hep DR, Santos AM. Acompanhamento de paciente com amputação de membro superior: um estudo de caso. Rev Contexto Saúde. 2011;11(20): 611-6.

2. Coelho A, Pereira I, Bettencourt F, Rosa C, Ladeira A. Desarticulação da anca-protetização: um caso clínico. In: Sessões clínicas do HFF. Serviço de Medicina Física e Reabilitação, Amadora, 2013.

3. Chamlian TR, Varanda RR, Pereira CL, Resende JM, Faria CC. Perfil epidemiológico dos pacientes amputados de membros inferiores atendidos no Lar Escola São Francisco entre 2006 e 2012. Acta Fisiátr. 2013 20(4):219-23.

4. Milioli R, Vargas MAO, Leal SMC, Montiel AA. Qualidade de vida em pacientes submetidos à amputação. Rev Enferm UFSM. 2012;2(2):311-9.

5. Demidoff AO, Pacheco FG, Sholl-Franco A. Membro-fantasma: o que os olhos não vêem, o cérebro sente. Ciências Cognição. 2007;12:234-9.

6. Mulvey MR, Bagnall AM, Johnson MI, Marchant PR. Transcutaneous electrical nerve stimulation (TENS) for phantom pain and stump pain following amputation in adults. Cochrane Database Syst Rev. 2010;(5):CD007264.

7. Vaso A, Adahan HM, Gjika A, Zahaj S, Zhurda T, Vyshka G, et al. Peripheral nervous system origin of phantom limb pain. Pain. 2014;155:1384-91.

8. Siddiqui S, Sifonios AN, Le V, Martinez ME, Eloy JD, Kaufman AG. Development of phantom limb pain after femoral nerve block. Case Rep Med. 2014. 2014:238453.

9. Probstner D, Thule LCS. Incidência e prevalência de dor fantasma em pacientes submetidos à amputação de membros: revisão de literatura. Rev Bras Cancerol. 2006;52(4):395-400

10. Dornelas LF. Uso da prótese e retorno ao trabalho em amputados por acidentes de transporte. Acta Ortop Bras. 2010;18(4):204-26. on others, personal and economic limitations or inadequacy of public policies, besides the personal and professional life changed by the surgery and living in fear of loss of physical integrity. The phantom limb pain it is a type of chronic post-surgical pain, whose incidence is high and that affects qualitatively the patients' lives, though often neglected by the medical team. It is a morbidity difficult to treat, and prevention is the most effective measure. ${ }^{19}$ It is, therefore, extremely important to have a larger number of studies related to this topic, since it adversely affects a large proportion of amputees, besides, their mechanisms are complex and not yet fully understood.

This type of pain is manifested in various ways, it may be characterized as mild to severe, intermittent or constant, like a stab, a shot, a tingle, a colic, a punch by a needled, and/or a burning feeling. ${ }^{8}$ The most reported type of pain in this study is the burn type $(42 \%-n=11)$ followed by needle punch $(36 \%-n=9)$ and tingle $(22 \%-n=7)$. Most of patients $(44 \%)$ reported a moderate pain intensity.

The results of the study indicate that patients with phantom limb pain have a lower quality of life, mainly related to the impairment of daily activities and an increase in anxiety levels, especially among young people (18-38 years) and depression in the elderly (60-80 years old). In the study by Vaz et al. ${ }^{20}$ the results were consistent, since the evaluated the sample in that study also showed a high prevalence of depression/ anxiety symptoms.

\section{CONCLUSION}

As well as the perception of body image, phantom limb pain leads to changes in the psychosocial profile, which result in a major impact on adherence to the rehabilitation program, the functional outcome and quality of life. Therefore, its evaluation and therapeutic management should be part of the approach of patients undergoing amputation surgery, giving the importance this type of clinical condition deserves to have.

\section{ACKNOWLEDGEMENTS}

The authors acknowledge the support received by the Scientific Initiation Scholarship Program (PIBIC) /CNPq /FAMERP.

11. Chamlian TR, Bonilha MMM, Macêdo MCM, Rezende F, Leal CAP. Prevalência de dor fantasma em amputados do Lar Escola São Francisco. Acta Fisiatr. 2012;19(3):167-70.

12. Silva MS. A imagem corporal na amputação: relação com a depressão, a ansiedade, a satisfação com o suporte social e a autoestima global [dissertação]. Porto: Faculdade de Psicologia e de Ciências da Educação da Universidade do Porto; 2013.

13. Pimenta CAM. Escalas de avaliação em dor. In: Texieira MD editor. Dor conceitos gerais. São Paulo: Limay; 1994. p.46-56

14. Botega NJ, Pondé MP, Lima MG, Guerreiro CAM. Validação da escala hospitalar de ansiedade e depressão HAD em pacientes epiléticos ambulatoriais. J Bras Psiquiatr. 1998;47(6):285-9.

15. Camelier A. Avaliação da qualidade de vida relacionada a saúde em pacientes com DPOC: estudo de base populacional com o SF-12 na cidade de São Paulo [tese]. São Paulo: Universidade Federal de São Paulo; 2004.

16. Atherton R, Robertson N. Psychological adjustment to lower limb amputation amongst prosthesis users. Disabil Rehabil. 2006 15;28(19):1201-9.

17. Resende MC, Cunha CPB, Silva AP, Jacó de Sousa S. Rede de relações e satisfação com a vida em pessoas com amputação de membros. Ciências Cognição. 2007;10(1):164-77.

18. Batista NNLAL, Luz MHBA. Vivências de pessoas com diabetes e amputação de membros. Rev Bras Enferm. 2012;65(2):244-50.

19. Sadatsune EJ, Leal PC, Clivatti J, Sakata RK. Dor crônica pós-operatória: fisiopatologia, fatores de risco e prevenção. Rev Dor. 2011;12(1):58-63.

20. Vaz IM, Roque V, Pimentel S, Rocha A, Duro H. Caracterização psicossocial de uma população portuguesa de amputados do membro inferior. Acta Méd Port. 2012;25(2):32-40. 